\title{
The Identification of Historical Tourism Potential in the Re-Branding of Kajoetangan Village
}

\author{
Baroroh Lestari*, Ita Rifiani P., Ellyn Eka W. \\ Business Administration Dept. \\ State Polytechnic of Malang \\ Malang, Indonesia \\ *baroroh.lestari@polinema.ac.id,ita_djatmika@yahoo.com, ekaellyn@gmail.com
}

\begin{abstract}
The Kajoetangan area, is one of the economic centers in the city of Malang, East Java, Indonesia, during the Dutch colonial period. The Kajoetangan area is divided into corridors and Village areas. The focus of this research is RW 1, 9 and 10 Kauman Village, Klojen District. This study aims to identify the potential for historical tourism in Kajoetangan Village. This study uses a qualitative approach using in-depth interviews, documentation and observation. Then the collected data were analyzed descriptively. The results showed that Kajoetangan Village has a large enough historical tourism potential. Thus, it is possible to re-branding from the center of the economy to become a historical tourist spot. There are several things that become obstacles in its development, including the low level of literacy of the people of Kajoetangan Village towards historical tourism. Therefore, in this study a recommendation can be made that efforts to increase community literacy and resource conservation are needed to save the potential of historical tourism resources from further damage.
\end{abstract} tourism

Keywords-tourism resources, Kajoetangan Village, historical

\section{INTRODUCTION}

Tourist attractions are one of the main components in the world of tourism. The number of tourist flows into and out of a certain city is determined by the number and degree of preference for a tourist object or location. Based on its nature, tourist attractions can be in the form of cultural, historical, natural and ancient sites. In developing the tourism industry in a city, it is not enough to have only a few tourist attractions / sites, but activities to protect and conserve tourism potential are very important. The conservation and protection of the potential of the tourism objects that are owned are very important determinants in the development of sustainable tourism [1-3].

Malang City is one of the cities in East Java, Indonesia which is blessed with many historical sites and colonial era buildings. Many of these colonial buildings are found in the Kajoetangan area. Kajoetangan, during the Dutch colonial period, was a place of trade. In general, Kajoetanganstraat is described as a leading trade corridor in Malang City and there is always social interaction in the community, because it is supported by a neat, orderly, and comfortable environment [4]. In 1914 the center of Malang was still located in the town square. Human settlement areas are located in the southwest of the town square (Taloen, Tongan, Sawahan and others), as well as along Kajoetangan, Oro-oro Dowo, Tjelaket, Klojenlor, and Rampal [4]. The current condition in Kajoetangan Street or known as Basuki Rahmad Street, can still be found Dutch colonial buildings. There are even shops from the Dutch colonial era that are still operating today, for example the Riang shop and Taman Tembakau shop. This research is focused on the Villages around Kajoetangan. In this Village there are still houses built during the colonial period. Some of the buildings are well maintained and inhabited, while some are in poor condition and uninhabited. Currently, Kajoetangan Village is included in the Kelurahan Kauman, Kecamatan Klojen. Therefore, the purpose of this study is to identify and describe the potential of historical tourism in the Kajoetangan Village in the re-branding of Kajoetangan.

\section{RESEARCH METHODS}

This study used a qualitative method which was conducted in the areas of RW 1, 9 and 10, Kelurahan Kauman Kecamatan Klojen. The data in this study were collected through in-depth interviews and observations. Interviews were conducted with the management of the Kajoetangan heritage Village (PokDarwis) and several home owners. Then after being collected, the data were analyzed using descriptive analysis.

\section{RESULTS AND DISCUSSION}

Cultural tourism, the rich material and non-material heritage of a certain area to realize various positive economic, ecological and social impacts. Tourism supports the development and enhancement of a destination, and increases public awareness of its cultural, special historical and preservation values. Cultural tourism includes history, art, culture, religion, sports and other forms of selective tourism [5]. Cultural heritage is an authentic and unrepeatable resource [5]. The results of observations at the research location indicate that Kajoetangan Village has several historical tourism potentials. The potential can be divided into old and historic 
building tours, religious sites, culinary and trade activities, river exploration and performances. The explanation of each of these potentials is as follows:

\section{A. Old and Historic Buildings Tours}

Kajoetangan Village was designated as a tourist destination for Malang City on April 22, 2018, by the Regional Secretary of Malang City, Drs. Wasto, SH, MH. In Malang City, until now only Kajoetangan Village has become a heritage tourist spot, so it is called the Kajoetangan Village. Kajoetangan Village is a historical tourist spot which has 23 old and historic buildings. The oldest building in the Village was founded in 1870 and has colonial and Betawi architecture. While the other buildings were built in the early 1900s-1980s. Most of the buildings are still original houses. Several buildings had undergone minor repairs and additions. This addition is tailored to the needs of the home owner. The formation of houses is related to the adaptation process of humans to nature, as an effort to respond to the natural conditions they occupy [6]. The appearance of the house can be distinguished according to:

- The appearance of the first colonial type house, with the features of the decorative building appearance or careful finishing (but not intricate), the doors and windows are high so that it seems strong upright (vertical), the arrangement of elements and components of the appearance tends to be one-sided;

- The look of the 1950s type (jengki type) has the characteristics of eliminating ornamentation, displays decorations in the form of geometric lines, straightforward detail completion, literally, the doors and windows are still in line with the colonial type, the arrangement is not one-sided, but the house doors have shifted sideways;

- The third type of appearance is the 1970s type, which is the type of house with the characteristics of not displaying ornament or decoration, non-special finishing, more literal, doors with wide windows or with nako windows, arrangement like the 1950s type; and

- The last type is the mixed type, which is a combination between the 1970s type and one of the existing types (colonial or 1950s types). Its characteristic is the part of the window door, namely the body of the building shows the 1970s type while the head of the building is from the colonial or 1950s. This type is present as a result of renovation (vermaakt) of an old building. In addition to the characteristics mentioned above, observation of paint color, material texture and ventilation can also complement the characteristics of each type [6].

Based on the results of the gardening, there are several houses that are included in the appearance of the first colonial type house. The houses include the Namsin house (with a gevel shape that characterizes the colonial type house. The 1870 house with high doors and windows and a half-shape. Then for the 1950s type there are among others the Rindu house and the chimney house where the doors and windows are arranged. It is no longer a cup, where the door slides to the side. Meanwhile, the third type of appearance, namely the 1970s type is found in the Music house. In the music house, there are wide windows and nako windows. These houses have certain unique characteristics and become their strengths. Attraction for tourists to visit Kajoetangan Village. In addition, these houses are an advantage for Kajoetangan Village which is not owned by other tourist Villages in Malang City.

\section{B. Religious Tourism}

Religion is one of the factors that motivates a person to travel and be involved in pilgrimages to various parts of the world [7]. In the last two decades, tourism has become an interesting thing because of the economic developments that have occurred. Religion in tourism is no exception $[8,9]$. Modern tourism is currently a function and symbol of an increasing number of religious activities such as festivals and pilgrimages $[9,10]$.

Religious tourism is a form that is motivated exclusively or strongly for religious reasons. One of the oldest types of tourism and a worldwide phenomenon of religious history, can be divided into various forms. Short-term religious tourism is distinguished by visits to the nearest pilgrimage center or religious conferences. The long term describes visits of several days or weeks to national and international pilgrimage sites or conferences. Forms of religious tourism organizations can be distinguished based on definite characteristics such as number of participants, transportation options, seasonal trips, and social structure. There are many religions in the world, but there are four major religions: Islam, Christian, Buddhism, and Hinduism. These religions are based on a set of beliefs and concepts. Most of these religions still have important ties to their early history and their place of origin. Each religion leaves behind a group of relics and inheritance [11].

In Kajoetangan Village, there are religious sites that can be used as religious tourism. Religious tourism can be carried out by tourists by visiting historical heritage places or making pilgrimages to the graves of scholars, kyai or community leaders. The religious site in Kajoetangan Village consists of the tomb of Mbah Honggo or Pangeran Honggo Koesoemo, who was the first reciting teacher of Malang Regent. Near to Mbah Honggo's grave is the tomb of Kyai Ageng Peroet (Pangeran Soero Adimerto). Around the grave there are also other old tombs. Not far from Mbah Honggo's grave is the tomb of R.M. Ng. Singowirio. In Kajoetangan Village, there are also old Langgar. It is estimated that the Langgar was founded around 1850 and is known as Langgar Shirotul Jannah. Around the Langgar there are also several old tombs. Many historical buildings or places have special meaning for religious communities, constituting a separate potential for the development of religious tourism [12].

In developing the social and economic benefits offered from religious tourism, religious destination authorities need to 
understand the behavior patterns of tourists [13]. Some researchers reveal that in understanding the tourism market, it starts with identifying tourists' motivations and the factors that drive their behavior [14,15]. Interestingly, despite the global importance and popularity of religious tourism, few researchers have investigated the experiences of religious tourists [13].

\section{Culinary Tours and Economic Activity}

At first, the Kajoetangan Village area was a residential area. Kajoetangan area is the corridor of Jalan Basuki Rahmat which has a main function as a trade and services area [4]. This corridor originally consisted of historic ancient colonial buildings lined up along Jalan Basuki Rahmat. In addition, the settlement area in the alleys of Kajoetangan has a function as a residential area. In this Village there are residential buildings in the Dutch colonial architectural style that still survive today.

Currently, culinary and trading activities are also growing and developing in the Kajoetangan Village. Culinary is a cultural exploration through food related to cooking, food and beverage as a basic human need and a source of energy for daily activities [16]. City development can include economic service activities for the surrounding area so that urban growth is closely related to the interests of its population, especially related to economic activities [17]. The results showed that currently in Kajoetangan Village, the economic activities are developing well. This is evidenced by the discovery of many places to do culinary tours while enjoying the atmosphere of the heritage Village of Kajoetangan. Snacks and drinks are sold in the form of traditional snacks and drinks such as cenil, ketan bubuk, ongol-ongol, sawut, sunduk urut, and gethuk. Apart from snacks, there are also traditional drinks in the form of dawet ireng ice and traditional herbal medicine. Tourists can enjoy these foods and drinks at relatively cheap prices. Then for trading activities include the krempyeng market, cafes and tobacco garden shops and many more.

\section{Explore the River}

Nature tourism globally has undergone a dramatic development since its introduction in the 1980s and has become an important part of the world tourism industry which is increasingly recognized. Ecotourism is a responsible natural tourism activity in an area by paying attention to several elements such as education, understanding, support for efforts to conserve natural resources, and increase the income of local communities [18]. This indicates that ecotourism activities require learning and educational activities in increasing tourists' knowledge in an effort to protect the environment. Ecotourism is also useful as a means of improving the community's economy [19]. Globally, natural tourism has shown a dramatic development since its creation in the 1980s and has become an important part of the world tourism industry and most importantly is gaining popularity. With the introduction of environmental education as an integral part of ecotourism to enhance customer satisfaction, many developing regions have utilized this one inherent element to effectively market their natural potential as a tourism product [20].
Kajoetangan Village, traversed by two rivers, namely the Sukun River and the Slayer River (Krangkeng). In river exploration tours, in the Kajoetangan Village there is also a water gate known as the Rolak. This Rolak was built in the Dutch colonial period with the aim of controlling water discharge, especially during the rainy season. Ecotourism has many impacts on people's lives and the environment [21]. For example, the Semeru tunnel found in Kampung Heritage. In the past, this tunnel was used by warriors to hide their weapons. Finally, there is trundakan sewu. Trundakan sewu is a number of stairs. In the past, this ladder was often used by government employees to get to the office from their respective homes.

\section{E. Events and Festivals Tourism}

Tourism is one of the fastest growing economic sectors. In fact, globally it has become an important component in the lives of many people and is a function of the socio-economic development of society. The result of this growth is increased diversification in the destination tourism industry that is competing for the market [22]. In line with the growth in the number of tourists, tourist expectations and demand will increase for unique experiences related to certain activities. Therefore, role events, especially tourism festivals need to be increased.

Festival, if defined based on generic and specific perceptions, can be expressed as conveying a special event organized with a certain cultural theme on a certain day or period, usually at a certain place, gathering people in mutual and direct contact to present the festival theme [23]. Apart from that, the festival is also an event that is encountered in almost all human cultures. Festivals are not only an important part of tourism but also an integral part of society. Festivals are used to create uniqueness and help an area stand out from the competition. This uniqueness will create demand and motivate visitors to visit a destination or offer alternatives that can assess their main purpose for traveling to a particular destination [24]. It is further argued that festivals and events can serve as a powerful tool to attract tourists during the low season and to create an impression and awareness of an area [25]. With the festival, tourists can see the natural, cultural and historical characteristics of an area as well as the lifestyle of the local community.

There are various events and festivals held at Kampung Kajoetangan Heritage. Some are organized by the management, youth organizations, the community, the government and other agencies. In the period 2018-2019 the events and activities carried out and involving Kajoetangan Village almost reached 40 activities. The events and festivals that are held include the wingko event, manual coffee brewing workshops, and others. With this large number and activities, it is not surprising that the number of visitors, both local and international tourists, continues to increase. Only in 2020, some have been postponed due to the Covid-19 pandemic. Therefore, in order for an event or festival to be successful, tourism actors are the main elements for the management of a tourist attraction [26]. 


\section{CONCLUSIONS AND RECOMMENDATIONS}

Based on the research that have been stated previously, it can be said that the Kajoetangan Village is very rich in historical tourism potential. Historical tourism in the Village can be divided into old and historic building tours, religious tourism, culinary tours and trade activities, explore the river as well as events and festivals tourism. With this potential, it is possible for the Kajoetangan Village to experience rebranding. The rebranding is from a trade area to a heritage tourist area.

Then the suggestion that can be recommended is the need to increase community literacy related to heritage tourism. In addition, it is also necessary to conserve the resources owned by Kajoetangan Village. With these two things, it is hoped that it can protect existing resources from damage in the future.

\section{ACKNOWLEDGMENT}

Acknowledgments were conveyed by the research team to the Director and Deputy Director 1 of State Polytechnic of Malang who have provided research funding to the research team through $\mathrm{P} 2 \mathrm{M}$ in the form of a Research Innovation of Research DIPA.

\section{REFERENCES}

[1] A. Pedersen, "Managing tourism at world heritage sites: A practical manual for world heritage site managers," 2002.

[2] S. Mann, "A Tourism Development Strategy for Ethiopia," World Bank, Washington, DC, 2007.

[3] A. Aman, "Identification and Documentation of Potential Tourism Resources: It's Management Practice in Focus in Jimma Town and its Vicinity, Southwestern Ethiopia," J Tour. Hosp., vol. 8, no. 418, pp. 269-2167, 2019.

[4] Antariksa, "Sejarah Dan Perkembangan Arsitektur Kawasan Kayutangan," Int. Work. Guest Lect. Util. Vrml Syst. Encourag. Community Particip. City Plan. Des. Process, 2013.

[5] B. Sančanin, G. Perić, and M. Stojiljković, "Cultural-historical resources as initiators of tourism development in Sremski Karlovci," Hotel Tour. Manag., vol. 7, no. 2, pp. 77-85, 2019

[6] N.J. Hersanti, “Tipologi Rancangan Pintu dan Jendela Rumah Tinggal Kolonial Belanda di Kayutangan Malang.” Universitas Brawijaya, 2008.

[7] A.A. Cristea, M.-S. Apostol, and T. Dosescu, "The role of media in promoting religious tourism in romania," Procedia-Social Behav. Sci., vol. 188 , pp. 302-306, 2015
[8] D. Amorim, J.L. Jiménez Caballero, and P. Almeida, "Motivation and tourists' loyalty in performing arts festivals: The mediator role of quality and satisfaction," 2019.

[9] K. Govender, N. Chiliya, T. Chuchu, E. Tafadzwa Maziriri, and T. Ndoro, "Religious tourism: an analysis of antecedents of the intention to participate in religious festivals," 2020.

[10] R. Sharpley and P. Sundaram, "Tourism: A sacred journey? The case of ashram tourism, India,” Int. J. Tour. Res., vol. 7, no. 3, pp. 161-171, 2005

[11] O.A.A. Jawabreh, "Distinction of Jordan as a destination for religious tourism,”J. Environ. Manag. Tour., vol. 8, no. 22, pp. 1171-1182, 2017.

[12] G. Ulung, Wisata Ziarah: 90 Destinasi Wisata Ziarah \& Sejarah di Jogja, Solo. Gramedia Pustaka Utama, 2013.

[13] T. Albayrak, R. Herstein, M. Caber, N. Drori, M. Bideci, and R. Berger, "Exploring religious tourist experiences in Jerusalem: The intersection of Abrahamic religions," Tour. Manag., vol. 69, pp. 285-296, 2018.

[14] C. Van Vuuren and E. Slabbert, "Travel behaviour of tourists to a South African holiday resort:: tourism," African J. Phys. Heal. Educ. Recreat. Danc., vol. 17, no. Special issue 1, pp. 694-707, 2011.

[15] P.A. Weaver, K.W. McCleary, J. Han, and P.E. Blosser, "Identifying leisure travel market segments based on preference for novelty," J. Travel Tour. Mark., vol. 26, no. 5-6, pp. 568-584, 2009.

[16] D. Fitrisia, R. Sibarani, and M. Ritonga, "Traditional food in the perspective of culinary linguistics," Int. J. Multidiscip. Res. Dev., vol. 5 no. 2, pp. 24-27, 2018.

[17] D. Arifia, S. Soedwiwahjono, and R.P. Utomo, "Pengaruh Perkembangan Kegiatan Perdagangan dan Jasa terhadap Perubahan Penggunaan Lahan di Kawasan Solo Baru," ARSITEKTURA, vol. 15, no. 1, pp. 1-9, 2017

[18] Pemerintah Republik Indonesia, "Peraturan Menteri Dalam Negeri Nomor 33 Tahun 2009 Tentang Pedoman Pengembangan Ekowisata D Daerah," Jakarta: Menteri Dalam Negeri, 2009.

[19] T. Muttaqin, R.H. Purwanto, and S.N. Rufiqo, "Kajian potensi dan strategi pengembangan ekowisata di cagar alam Pulau Sempu Kabupaten Malang provinsi Jawa timur,” J. Gamma, vol. 6, no. 2, 2013.

[20] N. Pookhao, "Community-based ecotourism: The transformation of local community," in SHS Web of Conferences, 2014, vol. 12, p. 1033

[21] M.O. Ukaegbu, N. Carr, and P.U. Okpoko, "Local people's perceptions of the potential implications of cultural revitalisation through tourism in Benin, Nigeria," J. Tour. Cult. Chang., vol. 18, no. 4, pp. 455-469, 2020

[22] A.T. Trends, "UNWTO/GTERC."

[23] L. Lyck, P. Long, and A.X. Grige, "Tourism, festivals and cultural events in times of crisis." Copenhagen Business School, 2012.

[24] G. ÖZDEMIR and O. ÇULHA, "Satisfaction and loyalty of festival visitors," Anatolia, vol. 20, no. 2, pp. 359-373, 2009.

[25] C. Goeldner and J. Ritchie, Tourism, 12th ed. Hoboken, N.J.: John Wiley \& Sons, 2012.

[26] A.A. Nathania, "Tourism \& travel agency management," Jakarta STP Trisakti. https//www. slideshare. net/agrifinanathania, 2013. 